\title{
Effects of fat replacement on properties of whole wheat bread
}

\author{
Patrícia Matos Scheuer ${ }^{1, *}$, Bruna Mattioni', Pedro Luiz Manique Barreto, \\ Flávio Martins Montenegro ${ }^{2}$, Cristiane Rodrigues Gomes-Ruffi², Sílvia Biondi², \\ Mariana Kilpp ${ }^{3}$, Alicia de Francisco ${ }^{1}$
}

\author{
${ }^{1}$ Federal University of Santa Catarina, UFSC, Florianópolis, SC, Brazil, ${ }^{2}$ Food Technology Institute, Campinas, SP, Brazil, \\ ${ }^{3}$ Federal Institute of Santa Catarina, IFSC, Florianópolis, SC, Brazil
}

\begin{abstract}
Bread characteristics are dependent upon the chemical composition and fiber content of the wheat flour used. A healthy diet can help prevent chronic diseases, where whole grains and fewer calories from fat are components of a healthy diet. The aims of this study were to determine the centesimal composition of wheat flour samples (whole, refined, and flour blends) along with their farinographic parameters (water absorption, development time and stability) and also to verify the specific volume, crumb texture profile and digital imaging of bread loaves made with $60 \%$ whole wheat flour and $3 \%$ fat or fat replacer. Increasing the whole wheat flour percentage in the blends also increased levels of protein, ash and insoluble fiber. All the farinographic parameters were also increased. Enzymatically modified starch was found to be an effective fat replacer in whole wheat loaves. The loaves made using fat replacer had the same specific volume and higher cell density as those made with fat, but exhibited different texture profile parameters such as higher hardness value and lower springiness value.
\end{abstract}

Uniterms: Wheat flour/centesimal composition. Whole wheat bread/characteristics. Fat/replacers. Food fibers.

A composição química da farinha de trigo e a presença de fibras afeta as características dos pães. Uma forma de contribuir com a prevenção de doenças crônicas não transmissíveis é através de alimentação saudável, incluindo grãos integrais na dieta alimentar e reduzindo as calorias de determinado alimento, substituindo a gordura. Assim, este trabalho tem como objetivo determinar a composição centesimal das amostras de farinha de trigo integral, refinada e as misturas entre elas; bem como os parâmetros farinográficos (absorção de água, tempo de desenvolvimento e estabilidade) das mesmas. Além disso, verificar volume específico, perfil de textura do miolo e análise de imagem de pães elaborados com $60 \%$ de farinha de trigo integral e com $3 \%$ de gordura ou com substituto de gordura. Os dados foram submetidos à análise de variância. À medida que aumenta o percentual de farinha integral, os teores de proteína, cinzas e fibra insolúvel alcançam valores significativamente maiores e a absorção de água fica maior na farinografia, bem como o tempo de desenvolvimento e a estabilidade. $\mathrm{O}$ amido modificado enzimaticamente utilizado na elaboração de pão com $60 \%$ de farinha de trigo integral funcionou como um efetivo substituto de gordura. O pão integral elaborado com substituto de gordura apresentou volume específico significativamente igual ao pão integral elaborado com gordura, porém com diferenças em relação a parâmetros do perfil de textura, maior firmeza e menor elasticidade além de maior densidade celular do que o pão elaborado com gordura.

Unitermos: Farinha de trigo/composição centesimal. Pão de trigo integral/características. Gordura/ substitutos. Fibras alimentares.

*Correspondence: P. M. Scheuer. Federal University of Santa Catarina-UFSC. Rod. Admar Gonzaga, 1346, Itacorubi, 88034-001 - Florianópolis - SC, Brasil. E-mail: patriciamatosscheuer@gmail.com 


\section{INTRODUCTION}

Wheat is one of the ten most important commodities globally (FAO, 2010) and numbers among the world's 'big three' cereal crops in terms of harvested area. Wheat is the main staple food for approximately $35 \%$ of the world's population (Torres, 2008).

Of all the cereal grains, wheat is unique because only wheat flour can form dough with the rheological properties required for the production of leavened bread and the broad variety of foods that have been developed owing to these attributes (Gianibelli et al., 2001). The grain structure (germ, scutellum, pericarp, aleurone layer and endosperm) which is extracted by the milling process affects the wheat flour composition (Kulp, Ponte, 1981). The unique properties of the wheat grain can be attributed primarily to the gluten-forming storage proteins of the endosperm. These dough-forming properties have made wheat the most important source of protein in the human diet (Gianibelli et al., 2001).

Including whole-grains in the diet can impact health and lifestyle because the functional components of wheat, such as protein and fiber, help reduce the risk of chronic diseases, stroke, hypertension, cardiovascular disease and cancers (Jones, Engleson, 2010), osteoporosis (USA, 2010) and obesity (Mann, Cummings, 2009). While lipids lubricate (Ghotra, Dyal, Narine, 2002) and plasticize the dough, in particular the gluten polymers (Mehta et al., 2009), fat should be restricted or reduced in the diet because it is the most important obesity factor (Valenzuela, Sanhueza, 2008) and non-communicable chronic disease factor (Brasil, 2005a).

The American Association of Cereal Chemists (AACC) has defined whole wheat flour as flour that has been prepared from wheat (other than durum) without altering the intact grain (AACC, 2000). All grains share the same basic anatomical structures: an outer bran layer, a germ fraction and a starchy endosperm (Hoseney, 1991). Grains are sources of abundant dietary fiber used to fortify foods, resulting in healthier products while grains also serve as a functional ingredient to improve the physical and structural properties of foods (Elleuch et al., 2011).

Several national dietary guidelines suggest eating plenty of whole-grain cereal foods without added fat (Truswell, 2002). These cereals have high starch content as their energy source and provide dietary fiber, nutritious protein plus lipids rich in essential fatty acids and micronutrients, such as vitamins, minerals, antioxidants and phytochemicals (Dewettinck et al., 2008).

A fat replacer is an ingredient that can provide the functions of fat yet with fewer calories (Choe et al., 2013): from 0 to $9 \mathrm{kcal} / \mathrm{g}$. Fat replacers mimic the sensory and physical functions of fat and confer flavor, mouth feel, texture, structure and lubricity to food (ADA, 2005). An ideal fat replacer should have the same functionality as fat, be partially or totally undigested, and non-toxic (Valenzuela, Sanhueza, 2008). Modified starch is one such fat replacer. It has specific applications such as increasing water holding capacity and minimizing starch syneresis (Miyazaki et al., 2006).

A food can be called a 'whole-grain food' when at least $51 \%$ of the grain ingredients are whole grains, according to the Whole Grain Council (2013). The Food and Drug Administration stipulate tha low-fat foods must contain $\leq 3 \mathrm{~g}$ fat per reference amount (FDA, 2010).

The aim of this study was to characterize the chemical and farinographic properties of whole wheat flour, refined wheat flour and different percentage blends of the two. Additionally, the specific volume, texture profile and image analysis of whole wheat bread made using fat or a fat replacer were analyzed.

\section{MATERIAL AND METHODS}

\section{Material}

Commercially refined wheat flour and whole wheat flour for bread making, harvested in 2012 and stored at $-18{ }^{\circ} \mathrm{C}$, were provided by Cooperativa Agrária Agroindustrial, Guarapuava, Paraná - Brazil. Selectamyx C150 an enzymatically modified corn starch used in this work as a commercial fat replacer, was provided by Dutch Starchs International, Netherlands. Moreover, commercial vegetable fat by Bunge (Brazil) was added to produce the bread dough.

Different blends of whole wheat flour (WF) and refined wheat flour (RF) were prepared and encoded: 100WF (100\%WF); 95.35WF (95.35\%WF + 4.65\%RF); $85 \mathrm{WF}(85 \% \mathrm{WF}+15 \% \mathrm{RF}) ; 60 \mathrm{WF}(60 \% \mathrm{WF}+40 \% \mathrm{RF})$; $35 \mathrm{WF}(35 \% \mathrm{WF}+65 \% \mathrm{RF}) ; 24.64 \mathrm{WF}(24.64 \% \mathrm{WF}+$ $75.36 \% \mathrm{RF}) ; 0 \% \mathrm{WF}(100 \% \mathrm{RF})$.

\section{Methods}

The chemical characteristics of the flours were measured in duplicate by AACC Approved Methods (AACC, 2000). Moisture (44-15A), lipids (30-25), ash (08-01), total starch (76-13), insoluble and soluble dietary fiber (IDF, SDF) (32-07) and protein were measured using the Kjeldahl method (46-10, nitrogen to protein conversion factor was 5.7 for refined wheat flour, 5.83 for whole wheat flour and 5.76 for flour blends). The farinogram curves 
were obtained in duplicate using Brabender Org Duisburg equipment (Brabender, Germany), model Type 820600 , method 54-21 (AACC, 2000), to measure and record the resistance of the dough to mixing under experimental conditions. The bread loaves were made in duplicate according to the optimized straight dough bread-making method 10-10B (AACC, 2000) with a 60 min fermentation time and based on the following formulation: whole wheat flour $(60 \%)$, refined wheat flour $(40 \%)$, sucrose $(6 \%)$, instant active dry yeast $(1.8 \%)$, chemically pure salt$\mathrm{NaCl}(1.5 \%)$, shortening (hydrogenated vegetable fat) or enzymatically-modified maize starch as a fat replacer (3\%), and tap water (Flander et al., 2007). The amount of water used corresponded to $86 \%$ of the water absorption content based on the farinogram and was optimized in preliminary assays (methodology adapted from Seyer and Gélinas (2009)). The ingredients were mixed at the second speed for 6 min (Oro, 2013; Flander et al., 2007) in a mixer (Líder model RPD 25, Brazil). The temperature of the dough was kept at $28-29{ }^{\circ} \mathrm{C}$ after mixing. Subsequently, 900 -g pieces of dough were placed in a proofing cabinet (Perfecta model CFC20, Brazil) at $30{ }^{\circ} \mathrm{C}$ and $85 \%$ relative humidity for $35 \mathrm{~min}$. The dough was then kneaded once, fermented for 17 min then kneaded again and fermented for the further $8 \mathrm{~min}$. The dough was sheeted by hand, placed into a rectangular mold $(9.5 \mathrm{~cm} \times 20 \mathrm{~cm} \times 4.5 \mathrm{~cm})$ and fermented for $24 \mathrm{~min}$. The dough was baked in a revolving oven (Líder model Ventile, Brazil) for $24 \mathrm{~min}$ at $180^{\circ} \mathrm{C}$. After cooling for $1 \mathrm{~h}$ at room temperature on metal grids, the technological parameters of the loaves were measured in triplicate. The finished loaves were rectangular with curved upper crust. The specific volume (SV), a technological parameter, was determined by the rapeseed displacement method 10-05 (AACC, 2000) and measured in duplicate. The crumb texture profile analysis (TPA) was performed on eight $25 \mathrm{~mm}$ cubes from the center of each loaf, according to method 74-10A (AACC, 2000). The TPA was measured in duplicate with a Texture Analyzer TA-XT Plus (Stable Micro System, Surrey, UK) equipped with a $50 \mathrm{~kg}$ load cell and a $36 \mathrm{~mm}$ aluminum cylindrical probe, which underwent two double compression tests up to $40 \%$ penetration of the original height (distance of $10 \mathrm{~mm}$ ) at a crosshead speed of $2 \mathrm{~mm} / \mathrm{s}$ with a $5 \mathrm{~s}$ gap between compressions of the crumb cubes. Four textural parameters were extracted from the curves: hardness (force necessary to attain a given deformation), springiness (rate at which a deformed material returns to the undeformed condition after the deforming force is removed), cohesiveness (strength of the internal bonds making up the body of the product) and chewiness (the energy required to masticate a solid product to a state ready for swallowing) (Szczesniak, 2002).
The crumb cell analysis was performed by scanning 1-cm-thick longitudinal and cross section samples of each loaf (Pourfarzad, Mohebbi, Mazaheri-Tehrani, 2012). Images of the three slices were acquired on a scanner (Multifunctional Brother DCP - 7065DN, Japan). The brightness and contrast parameters of the scanner program were set to the default values (zero) for all samples. The images were saved as bitmap files at a resolution of 150 dots per inch (dpi) in the Red-Green-Blue (RGB) color modern and bmp format. The values of the scanned images were obtained in pixels and converted into millimeters by using known length values. A single $40 \mathrm{~mm}$ x $40 \mathrm{~mm}$ square field of view was evaluated for each image. The free GNU Image Manipulation Program (GIMP), USA, version 2.6, was used to make the two measurements. After cropping, the images were pre-processed and converted to greyscale ( 8 bit). The pre-processing (change to grey-level), segmentation (manual thresholding tool with greyscale polarization into binary images from 0 to 106) and crumb grain measurements (extraction of parameters) were carried out using the ImageJ software Fiji 1.46 freeware, USA. The following crumb grain properties were extracted and calculated: number of cells (objects); mean cell area $\left(\mathrm{mm}^{2}\right)$; cell density $\left(\mathrm{n}^{\circ}\right.$ cell $\left./ \mathrm{mm}^{2}\right)$ and circularity.

Analysis of variance (ANOVA) and Tukey's test (significance level $\mathrm{p} \leq 0.05$ ) were used to determine the significance of the data. The statistical analysis and graphical representations were performed using STATISTICA 7.0 software, Copyright StatSoft (USA), Inc. 1984-2004.

\section{RESULTS AND DISCUSSION}

\section{Flour chemical analysis}

All flour samples (whole flour, refined flour and mixes) were analyzed chemically and the results are given in Table I.

The wheat flour moisture analysis results ranged from $11.94 \%$ for WF to $13.63 \%$ for RF. The moisture content of all of the samples followed the highest value of flour moisture (15\% for RF and 13\% for WF) (Brasil, 2005b).

The total protein content of the flours ranged from $10.91 \%$ to $13.85 \%$, corresponding to RF and $\mathrm{WF}$, respectively. The protein content of WF was significantly higher than the other flour samples $(\mathrm{p} \leq 0.05)$.

The RF protein values agree with the results obtained by Park et al. (2010) and Barros et al. (2010). The WF protein values agree with results obtained by 
TABLE I - Chemical characterization of flours

\begin{tabular}{cccccccc}
\hline $\begin{array}{c}\text { Sample } \\
(\% \mathbf{W F})\end{array}$ & $\begin{array}{c}\text { Moisture } \\
\mathbf{( \% )}\end{array}$ & $\begin{array}{c}\text { Protein } \\
\mathbf{( \% )}\end{array}$ & $\begin{array}{c}\text { Ash } \\
\mathbf{( \% )}\end{array}$ & $\begin{array}{c}\text { Lipids } \\
\mathbf{( \% )}\end{array}$ & $\begin{array}{c}\text { IDF } \\
\mathbf{( \% )}\end{array}$ & $\begin{array}{c}\text { SDF } \\
(\mathbf{\%})\end{array}$ & $\begin{array}{c}\text { Total Starch } \\
(\%)\end{array}$ \\
\hline 100 & $11.94^{\mathrm{b}} \pm 0.12$ & $13.85^{\mathrm{a}} \pm 0.59$ & $1.78^{\mathrm{a}} \pm 0.14$ & $2.80^{\mathrm{a}} \pm 0.55$ & $12.30^{\mathrm{a}} \pm 0.25$ & $2.90^{\mathrm{ab}} \pm 0.23$ & $55.46^{\mathrm{e}} \pm 0.66$ \\
95.35 & $12.59^{\mathrm{ab}} \pm 1.34$ & $12.90^{\mathrm{b}} \pm 0.05$ & $1.68^{\mathrm{ab}} \pm 0.18$ & $2.72^{\mathrm{a}} \pm 0.60$ & $11.89^{\mathrm{a}} \pm 0.07$ & $3.17^{\mathrm{a}} \pm 0.75$ & $54.74^{\mathrm{e}} \pm 0.55$ \\
85 & $12.50^{\mathrm{ab}} \pm 0.56$ & $12.88^{\mathrm{b}} \pm 0.07$ & $1.48^{\mathrm{abc}} \pm 0.17$ & $2.53^{\mathrm{a}} \pm 0.54$ & $10.72^{\mathrm{b}} \pm 0.52$ & $3.09^{\mathrm{ab}} \pm 0.23$ & $56.88^{\mathrm{de}} \pm 0.85$ \\
60 & $12.38^{\mathrm{b}} \pm 1.27$ & $12.23^{\mathrm{bc}} \pm 0.02$ & $1.15^{\mathrm{bcd}} \pm 0.18$ & $2.91^{\mathrm{a}} \pm 0.17$ & $8.07^{\mathrm{c}} \pm 0.09$ & $2.55^{\mathrm{ab}} \pm 0.17$ & $58.57^{\mathrm{cd}} \pm 0.73$ \\
35 & $13.01^{\mathrm{ab}} \pm 0.26$ & $11.72^{\mathrm{cd}} \pm 0.12$ & $0.92^{\mathrm{cde}} \pm 0.13$ & $1.74^{\mathrm{a}} \pm 0.33$ & $5.45^{\mathrm{d}} \pm 0.25$ & $2.09^{\mathrm{ab}} \pm 0.06$ & $60.86^{\mathrm{abc}} \pm 0.08$ \\
24.64 & $13.04^{\mathrm{ab}} \pm 0.52$ & $11.62^{\mathrm{cd}} \pm 0.10$ & $0.76^{\mathrm{de}} \pm 0.06$ & $1.86^{\mathrm{a}} \pm 0.22$ & $3.83^{\mathrm{e}} \pm 0.09$ & $1.71^{\mathrm{b}} \pm 0.06$ & $63.33^{\mathrm{ab}} \pm 1.04$ \\
0 & $13.63^{\mathrm{a}} \pm 0.49$ & $10.91^{\mathrm{d}} \pm 0.07$ & $0.53^{\mathrm{e}} \pm 0.06$ & $2.27^{\mathrm{a}} \pm 0.31$ & $1.93^{\mathrm{f}} \pm 0.08$ & $2.08^{\mathrm{ab}} \pm 0.41$ & $64.84^{\mathrm{a}} \pm 0.34$ \\
\hline
\end{tabular}

Mean values \pm standard deviation in the same column followed by a different letter are significantly different $(\mathrm{p} \leq 0.05)$, in duplicate. Results expressed as moisture basis, per-cent. N x 5.7 for RF, 5.83 for WF and 5.76 for mix of WF and RF samples. Variables: WF, Whole Wheat Flour; RF, Refined Wheat Flour; IDF, Insoluble Dietary Fiber; SDF, Soluble Dietary Fiber.

Barros et al. (2010) and Doblado-Maldonado et al. (2012). According to Oro (2013), variations in protein content can be caused by differences in the percentage of WR and RF in the flour mix. The environmental conditions and fertilization of wheat cultivars can significantly influence the protein content of the resulting flour (Turnbull, Rahman, 2002).

The ash content ranged between $0.53 \%$ and $1.78 \%$ for RF and WF, respectively (Table I).

Park et al. (2010) obtained similar ash content values for RF whereas Doblado-Maldonado et al. (2012) reported lower ash content for WF than the level found in the present study. The mineral fraction represented by the ash content of wheat was located primarily in the pericarp; therefore, the ash content should be low for RF, indicating low contamination in the milling process (Chiang, Chen, Chang, 2006).

In this study, WF displayed significantly higher protein and ash contents (Table I) $(\mathrm{p} \leq 0.05)$. These variations most likely occurred because both WF and RF were made from the same batch of grains.

The lipid content ranged from $1.74 \%$ to $2.91 \%$ (Table I) and did not differ significantly ( $\mathrm{p} \geq 0.05)$ across the wheat flour samples.

The lipid content of the WF was $2.80 \%$, higher than the values obtained by Oro (2013) (1.90 and 2.10\%) and by Prabhasankar and Rao (2001) (1.30 and 2.00\%). We found that WF had higher lipid content than RF, which agrees with the results of Chung et al. (2009).

The IDF was between the minimum value of $1.93 \%$ for RF and the maximum value of $12.30 \%$ for WF. The IDF values for $100 \% \mathrm{WF}$ and $95.35 \% \mathrm{WF}$ are significantly higher than the values of the other samples $(p \leq 0.05)$. For all other samples, the significance of the IDF decreased as the WF percentage decreased $(p \leq 0.05)$ (Table I). The
SDF content of the flours ranged from $3.17 \%$ to $1.71 \%$. The lowest SDF value was significantly lower than the other values, which did not differ significantly $(p \geq 0.05)$ (Table I).

The IDF increased proportionally to the WF percentage because whole grains have higher fiber content (USA, 2010) than refined grains, as the fiber is mainly located in the pericarp of wheat (Atwell, 2001). Similar results for WF IDF were observed by Seyer and Géllinas (2009).

The SDF for RF was $2.08 \%$, consistent with the values obtained by Seyer and Géllinas (2009).

The total starch content ranged from $54.74 \%$ to $64.84 \%$ and increased with decreasing WF percentage, reaching the highest significant value $(\mathrm{p} \leq 0.05)$ for $R F$ ( $0 \% \mathrm{WF})$.

Total starch values for high $\% \mathrm{WF}$ were in agreement with results obtained by Fujita and Figueroa (2003). Chanvrier et al. (2007) found a total starch content in RF of $67 \%$, a level similar to the results of this study.

\section{Flour farinography}

The farinographic characterization of all flour samples (whole flour, refined flour and flour mixes) are shown in Table II.

The water absorption (WA) content ranged from $57.40 \%$ to $62.85 \%$ (Table II).

Park et al. (2010) obtained similar WA contents for RF using a mixograph. Kihlberg et al. (2004) found similar WA contents for WF on a farinograph. WA values significantly increased for higher WF percentages $(\mathrm{p} \leq 0.05)$, in line with Sudha et al. (2007) and Noort et al. (2010). Rosell et al. (2001) reported that the differences in WA are caused predominantly by the greater number 
TABLE II - Farinographic characterization of flours

\begin{tabular}{cccc}
\hline $\begin{array}{c}\text { Sample } \\
\text { (\% WF) }\end{array}$ & $\begin{array}{c}\text { WA } \\
\mathbf{( \% )}\end{array}$ & $\begin{array}{c}\text { DT } \\
\text { (minutes) }\end{array}$ & $\begin{array}{c}\text { ST } \\
\text { (minutes) }\end{array}$ \\
\hline 100 & $62.85^{\mathrm{a}} \pm 0.21$ & $17.00^{\mathrm{a}} \pm 2.12$ & $38.00^{\mathrm{a}} \pm 2.12$ \\
95.35 & $62.40^{\mathrm{a}} \pm 0.00$ & $13.75^{\mathrm{ab}} \pm 1.06$ & $38.50^{\mathrm{a}} \pm 0.00$ \\
85 & $60.75^{\mathrm{b}} \pm 0.49$ & $11.00^{\mathrm{bc}} \pm 0.00$ & $30.50^{\mathrm{a}} \pm 12.73$ \\
60 & $57.70^{\mathrm{c}} \pm 0.00$ & $10.25^{\mathrm{bc}} \pm 0.35$ & $26.00^{\mathrm{ab}} \pm 2.83$ \\
35 & $57.40^{\mathrm{d}} \pm 0.00$ & $8.50^{\mathrm{c}} \pm 1.41$ & $10.00^{\mathrm{b}} \pm 0.00$ \\
24.64 & $57.50^{\mathrm{d}} \pm 0.14$ & $9.00^{\mathrm{c}} \pm 0.00$ & $8.50^{\mathrm{b}} \pm 0.71$ \\
0 & $59.70^{\mathrm{d}} \pm 0.28$ & $2.75^{\mathrm{d}} \pm 0.35$ & $10.00^{\mathrm{b}} \pm 0.00$ \\
\hline
\end{tabular}

Mean values \pm standard deviation in the same column followed by a different letter are significantly different ( $\mathrm{p} \leq 0.05)$, in duplicate. Farinographic properties: WA, Water Absorption (based on 14\% humidity); DT, Development Time; ST, Stability. Variable: WF, Whole Wheat Flour.

of hydroxyl groups that exist in the fiber structure, which allows for more water interaction through hydrogen bonding. WA is influenced by protein content and starch damage caused by the milling process (Bockstaele et al., 2008; Gélinas et al., 2009), which may explain the $100 \%$ WF characterization in this study. Moreover, the fiber present in WF increased the WA(Gómez, Gonzáles, Oliete, 2012).

For the development time (DT), the $100 \% \mathrm{WF}$ (17.00 $\mathrm{min})$ and $95.35 \% \mathrm{WF}$ (13.75 min) had significantly higher values $(\mathrm{p} \leq 0.05)$ than the RF $(2.75 \mathrm{~min})$ (Table II).

Kihlberg et al. (2004) found a maximum DT of 15 min for WF. DT increases when fiber fractions are added to the flour because the fiber absorbs water (Noort et al., 2010), a phenomenon also observed in the present study (17 min).

For stability (ST), the $100 \%$ WF (38.00 min) and $95.35 \% \mathrm{WF}$ (38.50 min) had significantly higher values $(\mathrm{p} \leq 0.05)$ than RF (10.00 min) (Table II).

The ST values of this study agree with results obtained by Indrani and Rao (2007), who found that dough ST can be characterized as an indicator parameter of mixing resistance; and also mirrored the results of
Gómez et al. (2003), who found that the addition of fiber increases dough ST. Seyer and Gélinas (2009) examined RF and reported a DT of $2.6 \mathrm{~min}, \mathrm{ST}$ of $10.7 \mathrm{~min}, 11.2 \%$ protein content, and $0.52 \%$ ash content. These findings are similar to the results observed in this study.

\section{Bread specific volume}

The SV of the loaves made with $60 \% \mathrm{WF}$ are given in Table III. No significant difference $(\mathrm{p} \geq 0.05)$ was found between the loaves made using the fat replacer $\left(1.87 \mathrm{~cm}^{3} / \mathrm{g}\right)$ or fat $\left(2.00 \mathrm{~cm}^{3} / \mathrm{g}\right)$ (Table III).

The greater SV seen in the fat loaf might have been due to the crystalline lipid that coats the gluten proteins and starch granules (Chin et al., 2010). The added solid lipid uniformly distributes within the gluten network between the starch granules, forming thin and easily expandable gluten films with less tendency to contract after expansion (Watanabe, Yokomizo, Eliasson, 2003). Shortening works as a gas-stabilizing agent during bread making and influences the incorporation of air into the dough (Alvarez-Jubete et al., 2010) which in turn affects loaf volume (Pareyt et al., 2011).

TABLE III - Specific volume and texture profile analysis of bread loaves

\begin{tabular}{lccccc}
\hline \multirow{2}{*}{ Samples } & \multirow{2}{*}{$\begin{array}{c}\text { SV } \\
\left(\mathbf{c m}^{3} / \mathbf{g}\right)\end{array}$} & $\begin{array}{c}\text { Hardness } \\
(\mathbf{g})\end{array}$ & Springiness & Cohesiveness & $\begin{array}{c}\text { Chewiness } \\
(\mathbf{g})\end{array}$ \\
\cline { 3 - 6 } & & $1162.514^{\mathrm{a}} \pm 357.714$ & $0.500^{\mathrm{b}} \pm 0.169$ & $0.455^{\mathrm{a}} \pm 0.122$ & $306.19^{\mathrm{a}} \pm 228.67$ \\
\hline $\begin{array}{l}\text { Loaf made with fat } \\
\text { replacer }\end{array}$ & $1.8734^{\mathrm{a}} \pm 0.2325$ & & & & \\
Loaf made with fat & $2.0049^{\mathrm{a}} \pm 0.1030$ & $686.038^{\mathrm{b}} \pm 149.166$ & $0.672^{\mathrm{a}} \pm 0.140$ & $0.530^{\mathrm{a}} \pm 0.069$ & $241.31^{\mathrm{a}} \pm 69.32$ \\
\hline
\end{tabular}

Mean values \pm standard deviation in the same column followed by a different letter are significantly different $(\mathrm{p} \leq 0.05)$, in duplicate. SV, Specific Volume. 
TABLE IV - Image analysis parameters of bread loaves

\begin{tabular}{lcccc}
\hline Samples & $\begin{array}{c}\text { Number of cells } \\
\text { (objects) }\end{array}$ & $\begin{array}{c}\text { Mean cell area } \\
\left(\mathbf{m m}^{\mathbf{2}}\right)\end{array}$ & $\begin{array}{c}\text { Cell density } \\
\left(\mathbf{n}^{\mathbf{0}} \mathbf{c e l l} / \mathbf{m m}^{\mathbf{2}}\right)\end{array}$ & Circularity \\
\hline Loaf made with fat replacer & $1431.50^{\mathrm{a}} \pm 286.37$ & $0.117^{\mathrm{a}} \pm 0.029$ & $12255.34^{\mathrm{a}} \pm 586.56$ & $0.826^{\mathrm{a}} \pm 0.011$ \\
Loaf made with fat & $1201.50^{\mathrm{a}} \pm 3.54$ & $0.211^{\mathrm{a}} \pm 0.017$ & $5688.42^{\mathrm{b}} \pm 301.99$ & $0.812^{\mathrm{a}} \pm 0.006$ \\
\hline
\end{tabular}

Mean values \pm standard deviation in the same column followed by a different letter are significantly different ( $\mathrm{p} \leq 0.05)$, in triplicate.

The SV value for the fat loaf agrees with results obtained for a loaf prepared with RF, which had an SV range of 1.80 to $2.05 \mathrm{~cm}^{3} / \mathrm{g}$ (El-Porai et al., 2013), and for a loaf prepared with $100 \% \mathrm{WF}$, which had an SV range of 2.82 to $4.14 \mathrm{~cm}^{3} / \mathrm{g}$ (Seyer, Gélinas, 2009).

The SV value of the fat replacement loaf agrees with results obtained for bread made with $0.5 \%$ guar gum (SV of $2.5 \mathrm{~cm}^{3} / \mathrm{g}$ ) (Skara et al., 2013), 1.4\% $\beta$-glucan (SV of $2.26 \mathrm{~cm}^{3} / \mathrm{g}$ ) (Skendi et al., 2010), 40\% amaranth flour (SV of $2.51 \mathrm{~cm}^{3} / \mathrm{g}$ ) (Sanz-Penella et al., 2012) or with $10 \%$ fiber (SV of just over $2.3 \mathrm{~cm}^{3} / \mathrm{g}$ after 6 days of storage) (Rosell, Santos, 2010).

\section{Bread crumb texture profile analysis (TPA)}

The bread crumb texture profile analysis of loaves made with $60 \% \mathrm{WF}$ and fat replacer or fat are reported in Table III. The TPA results showed significant differences $(\mathrm{p} \leq 0.05)$ in bread hardness and springiness between loaves made using fat replacer (1162.514 $\mathrm{g}$ and 0.500 , respectively) and loaves made with hydrogenated vegetable fat (686.038 $\mathrm{g}$ and 0.678 , respectively) (Table III). No significant differences ( $\mathrm{p} \geq 0.05$ ) were observed for cohesiveness and chewiness (Table III).

Similar hardness results for bread made with fat were obtained in breads made with $10 \%$ fiber mix and no fat (Rosell, Santos, 2010); in breads with $2 \%$ cellulose after 72 h of storage (Gómez et al., 2003); and in breads made with $2.5 \%$ fat (O'Brien et al., 2003).

Similar hardness results for bread with fat replacer were obtained in breads made with $2.5 \%$ inulin powder (O'Brien et al., 2003), a carbohydrate-based fat replacer that results in higher crumb hardness than in bread made with fat. The increase in crumb hardness could be a consequence of the thickening of walls surrounding the gas cells that occurs upon the addition of hydrocolloids into bread formulas (Rosell, Rojas, Barber, 2001). Furthermore, an increase in bread hardness may result from a decrease in the total area of the gas cell; greatest crumb hardness is usually observed in breads with the lowest loaf volume.

Cohesiveness is higher in loaves made with fat, as observed by Collar et al. (1999), while more cohesive dough results in higher SV and softer loaves.

In this study, the loaf containing fat had a softer breadcrumb than the loaf containing the fat replacer. Furthermore, the loaf made using the fat replacer had lower springiness (capacity to return to undeformed condition after deforming force is removed from the bread) than the loaf made with fat.

\section{Image analysis}

There were no significant differences $(p \geq 0.05)$ between the image analysis parameters (number of cells, mean cell area and circularity of bread loaves) for the loaves made with fat and those containing fat replacer (Table IV).

The bread made with fat replacer had significantly higher cell density $\left(12255.34 \mathrm{n}^{\circ}\right.$ cell $\left./ \mathrm{mm}^{2}\right)(\mathrm{p} \leq 0.05)$ than the bread made with fat $\left(5688.42 \mathrm{n}^{\circ}\right.$ cell $\left./ \mathrm{mm}^{2}\right)$ (Table IV). The cell density was calculated by dividing the number of cells by the mean cell area.

Bread made using the fat replacer had a more compact structure (Figure 1A, 1B) with smaller pores than the bread made with fat (Figure 1C, 1D).

\section{Breadcrumb Digital Images Schematic diagram}

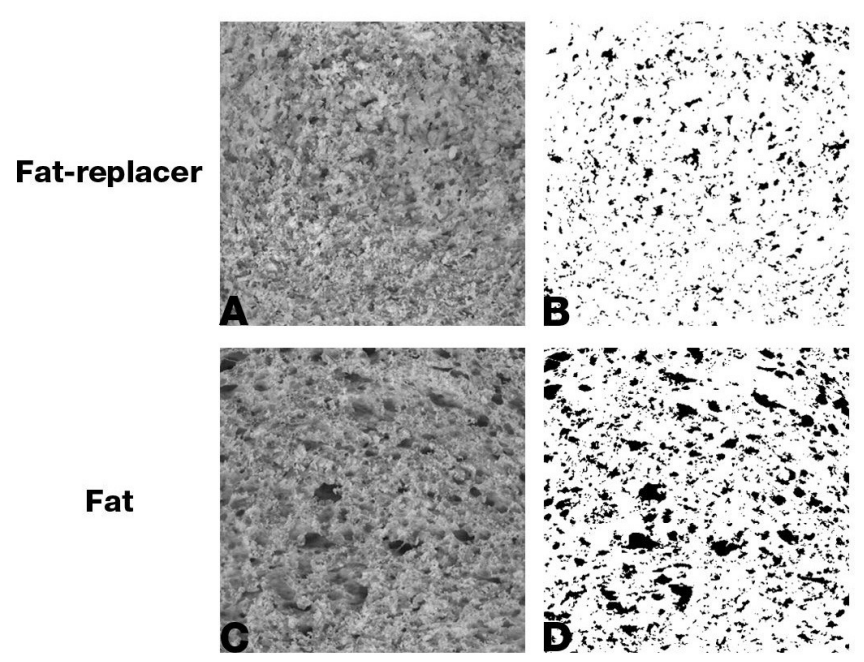

FIGURE 1 - Breadcrumb image analysis (40 mm x $40 \mathrm{~mm}$ crumb area). 
The bread made with fat replacer (Figure 1A, 1B) had smaller pores (cell area $<0.1 \mathrm{~mm}^{2}$ ) and a lower cell density than the bread made with fat (Figure 1C, 1D). These results agree with those obtained by Polaki et al. (2010) in oat bread. The main function of the fat ingredient is to entrap air into the batter during mixing, which could explain the loss of pore size in the bread with fat replacer. When the air begins to expand, the fat crystals that are adsorbed to the air-water interface melt and release the fat-water interface for bubble expansion. Large numbers of adsorbed crystals release sufficient interface to allow the bubbles to expand without rupturing (Kocer et al., 2007). Different breadcrumb textures might be attributed to the different amount of air incorporated into the dough as a consequence of the differing consistency of the breads (Rosell, Santos, 2010).

According to Polaki et al. (2010), the pore distribution reveals information about the effect on bread structure. Pores can be small $\left(\right.$ area $\left.<4 \mathrm{~mm}^{2}\right)$, medium (area 4-8 $\mathrm{mm}^{2}$ ) or large (area $>8 \mathrm{~mm}^{2}$ ).

The pores of the breads made with fat (Figure 1C, 1D) and with fat replacer (Figure 1A, 1B) were characterized as small (Figure 2). Large pores, with cell area 8-10 and $14-16 \mathrm{~mm}^{2}$, were especially evident in breadcrumbs made with fat (Figure 2), in agreement with results obtained in polydextrose bread by Polaki et al. (2010).

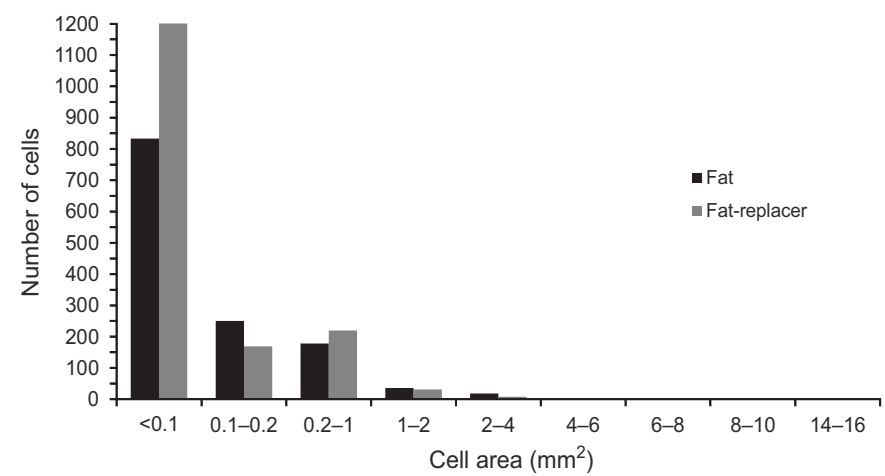

FIGURE 2 - Histogram: Number of cells by cell area of loaves produced with fat and with fat replacer.

No significant differences were observed in cell circularity between the bread made with fat replacer and the bread made with fat. Rosell and Santos (2010) showed that use of inulin, hydroxypropylmethylcellulose or locust bean gum did not influence the mean cell area.

Bread made with fat replacer presented a smaller specific volume, a smaller mean cell area and a higher cell density, in agreement with results found in wheat bread made with corn and oat (Hruskova et al., 2012).

\section{CONCLUSION}

As expected, WF (100\%) had significantly higher values for protein, lipid, ash, fiber and total starch contents than RF. Higher percentages of WF were associated with greater WA on farinograph and also increased the dough's DT and ST. These results can be attributed to the increase in the fiber, which affects the technological parameters of the bread.

An increase in crumb hardness and a decrease in crumb springiness were observed in breads with a fat replacer, as compared with fat-containing bread.

Enzymatically-modified starch was found to be an effective fat replacer in whole wheat loaves - a staple food that besides being a good source of fiber also contains fewer calories.

\section{ACKNOWLEDGEMENTS}

The authors would like to thank the Fundação de Amparo à Pesquisa e Inovação do Estado de Santa Catarina (FAPESC) for the financial support, the Cooperativa Agrária Agroindustrial for providing the wheat flours and also Dutch Starchs International for providing the commercial fat replacer.

\section{REFERENCES}

AMERICAN ASSOCIATION OF CEREAL CHEMISTS. AACC. Approved methods of analysis. 10ed. St Paul: AACC International, 2000. $1018 \mathrm{p}$.

AMERICAN DIETETIC ASSOCIATION. ADA. Position of the american dietetic association: fat replacers. J. Am. Diet. Assoc., v.105, n.2, p.266-275, 2005.

ALVAREZ-JUBETE, L.; AUTY, M.; ARENDT, E.K.; GALLAGHER, E. Baking properties and microstructure of pseudocereal flours in gluten free bread formulations. Eur. Food Res. Technol., v.230, n.3, p.437-445, 2010.

ATWELL, W.A. Wheat flour. Eagen press handbook series. St. Paul: AACC, 2001. 134 p.

BARROS, F.; ALVIOLA, J.N.; ROONEY, L.W. Comparison of quality of refined and whole wheat tortillas. J. Cereal Sci., v.51, n.1, p.50-56, 2010. 
BOCKSTAELE, F.V.; LEN, I.D.; EECKHOUT, M.; DEWETTINCK, K. Rheological properties of wheat flour dough and the relationship with bread volume I. Creeprecovery measurements. Cereal Chem., v.85, n.6, p.753$761,2008$.

BRASIL. Ministério da Saúde. Secretaria de Atenção à Saúde. Coordenação Geral da Política de Alimentação e Nutrição. Guia Alimentar para População Brasileira. Série A. Normas e Manuais Técnicos. Brasília, 2005a. Available at: http:// www.sonutricao.com.br/downloads/Guia_Alimentar_ Populacao_Brasileira.pdf. Accessed on: Aug. 2014.

BRASIL. Ministério da Agricultura. Pecuária e Abastecimento. Instrução Normativa $n^{\circ} 8$ de 02 de junho de 2005 b. Regulamento Técnico de Identidade e de Qualidade da Farinha de Trigo. Diário Oficial da República Federativa do Brasil, Brasília, DF, 3 jun. 2005b. Seção 1, n.105, p.91.

CHANVRIER, H.; UTHAVAKUMARAN, S.; LILLFORD, P. Rheological properties of wheat flour processed at low levels of hydration: Influence of starch and gluten. J. Cereal Sci., v.45, n.3, p.263-274, 2007.

CHIANG, S.; CHEN, C.; CHANG, C. Effect of wheat flour protein compositions on the quality of deep-fried gluten balls. Food Chem., v.97, n.4, p.666-673, 2006.

CHIN, N.L.; RAHMAN, R.A.; HASHIM, D.M.; KOWNG, S.Y. Palm oil shortening effects on baking performance of white bread. J. Food Process Eng., v.33, n.3, p.413-433, 2010.

CHOE, J.; KIM, H.; LEE, J.; KIM, Y.; KIM, C. Quality of frankfurter-type sausages with added pig skin and wheat fiber mixture as fat replacers. Meat Sci., v.93, n.4, p.849$854,2013$.

CHUNG, O.K.; OHM, J.B.; RAM, M.S.; PARK, S.H.; HOWITT, C.A. Wheat lipids in wheat chemistry and technology. In: KHAN, K.; SHEWRY, P. R. Wheat: chemistry and technology. St. Paul: AACC, 2009. p.363-399.

COLLAR, C.; ANDREU, P.; MARTÍNEZ, J.C.; ARMERO, E. Optimization of hydrocolloid addition to improve wheat bread dough functionality: a response surface methodology study. Food Hydrocolloid, v.13, n.6, p.467-475, 1999.
DEWETTINCK, K.; BOCJSTAELE, F.V.; KÜHNE, B.; VAN DE WALlE, V.; COURTENS, T.M.; GELLYNCK, X. Nutritional value of bread: Influence of processing, food interaction and consumer perception. J. Cereal Sci., v.48, n.2, p.243-257, 2008.

DOBLADO-MALDONADO, A.F.; PIKE, O.A.; SWELEY, J.C.; ROSE, D.J. Key issues and challenges in whole wheat flour milling and storage. J. Cereal Sci., v.56, n.2, p.119$126,2012$.

ELLEUCH, M.; BEDIGIAN, D.; ROISEUX, O.; BESBES, S.; BLECKER, C.; ATTIA, H. Dietary fibre and fibre-rich byproducts of food processing: characterisation, technological functionality and commercial applications: a review. Food Chem., v.124, n.2, p.411-421, 2011.

EL-PORAI, E.S.; SALAMA, A.E.; SHARAF, A.M.; HEGAZY, A.I.; GADALLAH, M.G.E. Effect of different milling processes on Egyptian wheat flour properties and pan bread quality. Ann. Agric. Sci., v.58, n.1, p.51-59, 2013.

FOOD AND AGRICULTURE ORGANIZATION OF THE UNITED NATIONS. FAO. For a world without hunger. Available at: http://faostat3.fao.org/home/index. html\#VISUALIZE_TOP_20. Accessed on: July 2012.

FOOD AND DRUG ADMINISTRATION. FDA. Nutrition labeling and education requirements. Available at: $<$ http:// www.fda.gov/ICECI/Inspections/InspectionGuides/ ucm114092.htm> Accessed on: Apr. 2013.

FLANDER, L.; SALMENKALLLIO-MARTILA, M.; SUORTTI, T.; AUTIO, K. Optimization of ingredients and baking process for improved wholemeal oat bread quality. LWT-Food Sci. Technol., v.40, n.5, p.860-870, 2007.

FUJITA, A.H.; FIGUEROA, M.O.R. Composição centesimal e teor de $\beta$-glucanas em cereais e derivados. Ciênc. Tecnol. Aliment., v.23, n.2, p.116-120, 2003.

GÉLINAS, P.; MORIN, C.; REID, J.F.; LACHANCE, P. Wheat cultivars grown under organic agriculture and the bread making performance of stone-ground whole wheat flour. Int. J. Food Sci. Technol., v.44, n.3, p.525-530, 2009.

GHOTRA, B.S.; DYAL, S.D.; NARINE, S.S. Lipid shortenings: a review. Food Res. Int., v.35, n.10, p.1015-1048, 2002. 
GIANIBELLI, M.C.; LARROQUE, O.R.; MACRITCHIE, R.; WRIGLEY, C.W. Biochemical, genetic, and molecular characterization of wheat glutenin and its component subunits. Cereal Chem., v.78, n.6, p.635-646, 2001.

GÓMEZ, M.; GONZÁLES, J.; OLIETE, B. Effect of extruded wheat germ on dough rheology and bread quality. Food Bioprocess Technol., v.5, n.6, p.2409-2418, 2012.

GÓMEZ, M.; RONDA, F.; BLANCO, C.A.; CABALLERO, P.A.; APESTEGUÍA, A. Effect of dietary fibre on dough rheology and bread quality. Eur. Food Res. Technol., v.216, n.1, p.51-56, 2003.

HOSENEY, R.C. Principios de ciencia y tecnologia de los cereales. Zaragoza: Acribia, 1991. 321 p.

HRUSKOVA, M.; SVEC, I.; HOFMANOVA, T.; DVORAKOVA, J. Image analysis - comparison of recipe composition effect. Procedia Eng., v.42, p.955-963, 2012.

INDRANI, D.; RAO, G.V. Rheological characteristics of wheat flour dough as influenced by ingredients of parotta. J. Food Eng., v.79, v.100-105, 2007.

JONES, J.M.; ENGLESON, J. Whole grains: benefits and challenges. Annu. Rev. Food Sci. Technol., v.1, p.19-40, 2010 .

KIHLBERG, I.; JOHANSSON, L.; KOHLER, A.; RISVIK, E. Sensory qualities of whole wheat pan bread - influence of farming system, milling and baking technique. J. Cereal Sci., v.39, n.1, p.67-84, 2004.

KOCER, D.; HICSASMAZ, Z.; BAYINDIRLI, A.; KATNAS, $\mathrm{S}$. Bublle and pore formation of the high-ratio cake formulation with polydextrose as a sugar- and fat-replacer. J. Food Eng., v.78, n.3, p.953-964, 2007.

KULP, K.; PONTE, J. G. Staling of white pan bread: Fundamental causes. Crit. Rev. Food Sci. Nutr., v.15, n.1, p.1-48, 1981.

MANN, J.I.; CUMMINGS, J.H. Possible implications for health of the different definitions of dietary fibre. Nutr. Metab. Cardiovasc. Dis., v.19, n.3, p.226-229, 2009.

MEHTA, K.L.; SCANLON, M.G.; SAPIRSTEIN, H.D.; PAGE, J.H. Ultrasonic investigation of the effect of vegetable shortening and mixing time on the mechanical properties of bread dough. J. Food Sci., v.74, n.9, p.E455-E461, 2009.
MIYAZAKI, M.; HUNG, P.V.; MAEDA, T.; MORITA, N. Recent advances in application of modified starches for breadmaking. Trends Food Sci. Technol., v.17, n.11, p.591$599,2006$.

NOORT, M.W.J.; HAASTER, D.V.; HEMERY, Y.; SCHOLS, H.A.; HAMER, R.J. The effect of particle size of wheat bran fractions on bread quality - Evidence for fibre - protein interations. J. Cereal Sci., v.52, n.1, p.59-64, 2010.

O’BRIEN, C.M.; MUELLER, A.; SCANNELL, A.G.M.; ARENDT, E.K. Evaluation of the effects of fat replacers on the quality of wheat bread. J. Food Eng., v.56, n.2-3, p.265-267, 2003.

ORO, T. Adaptação de métodos para avaliação da qualidade tecnológica de farinha de trigo integral. Florianópolis, 2013. 157 p. [Thesis of PhD degree. Center of Agricultural Sciences. Federal University of Santa Catarina].

PAREYT, B.; FINNEI, S.M.; PUTSEYS, J.A.; DELCOUR, J. Lipids in bread making: Sources, interactions, and impact on bread quality. J. Cereal Sci., v.54, n.3, p.266-279, 2011.

PARK, C.; KANG, C.; CHENG, Y.; JUNG, W.; WOO, S. Influence of puroindoline genotypes on grain characteristics, physico-chemical properties of flour and end-use quality of korean wheats. Breeding Sci., v.60, n.3, p.233-242, 2010.

POLAKI, A.; XASAPIS, P.; FASSEAS, C.; YANNIOTIS, S.; MANDALA, I. Fiber and hydrocolloid content affect the microstructural and sensory characteristics of fresh and frozen stored bread. J. Food Eng., v.97, n.1, p.1-7, 2010.

POURFARZAD, A.; MOHEBBI, M.; MAZAHERI-TEHRANI, M. Interrelationship between image, dough and Barbari bread characteristics; use of image analysis to predict rheology, quality and shelf life. Int. J. Food Sci. Tech., v.47, n.7, p.1354-1360, 2012.

PRABHASANKAR, P.; RAO, P. H. Effect of different milling methods on chemical composition of whole wheat flour. Eur Food Res. Technol., v.213, p.465-469, 2001.

ROSELL, C.M.; ROJAS, J.A.; BARBER, C.B. Influence of hydrocolloids on dough rheology and bread quality. Food Hydrocolloid, v.15, n.1, p.75-81, 2001.

ROSELL, C.M.; SANTOS, E. Impact of fibers on physical characteristics of fresh and staled bake off bread. J. Food Eng., v.98, n.2, p.273-281, 2010. 
SANZ-PENELLA, J.M.; WRONKOWSKA, M.; SORALSMIETANA, M.; HAROS, M. Effect of whole amaranth flour on bread properties and nutritive value. $L W T$ - Food Sci. Technol., v.50, n.2, p.679-685, 2013.

SEYER, M.; GÉLINAS, P. Bran characteristics and wheat performance in whole wheat bread. Int. J. Food Sci. Technol., v.44, n.4, p.688-693, 2009.

SKARA, N.; NOVOTNI, D.; CUKELJ, N.; SMERDEL, B.; CURIC, D. Combined effects of inulin, pectin and guar gum on the quality and stability of partially baked frozen bread. Food Hydrocolloid, v.30, n.1, p.428-436, 2013.

SKENDI, A.; BILIADERIS, C.G.; PAPAGEORGIOU, M.; IZYDORCZYK, M.S. Effects of two barley $\beta$-glucan isolates on wheat flour dough and bread properties. Food Chem., v.119, n.3, p.1159-1167, 2010.

SUDHA, M.L.; VETRIMANI, R.; LEELAVATHI, K. Influence of fibre from different cereals on the rheological characteristics of wheat flour dough and on biscuit quality. Food Chem., v.100, n.4, p.1365-1370, 2007.

SZCZESNIAK, A.S. Texture is a sensory property. Food Qual. Prefer., v.13, n.4, p.215-225, 2002.

TORRES, G.A.M. Proteínas de reserva do trigo: o pão ou o biscoito nosso de cada dia (2008). Available at: <www. agrolink.com.br/cereaisdeinverno/NoticiaDetalhe. aspx? codNoticia $=62613>$ Accessed on: Jan. 2008.
TRUSWELL, A.S. Cereal grains and coronary heart disease. Eur. J. Clin. Nutr., v.56, n.1, p.1-14, 2002.

TURNBULL, K.M.; RAHMAN, S. Endosperm texture in wheat. J. Cereal Sci., v.36, n.3, p.237-337, 2002.

UNITED STATES OF AMERICA. Department of Agriculture and Department of Health and Human Services. Dietary guidelines for americans, 2010. 7.Ed. Washington: Government Printing Office. Available at: $<$ www. dietaryguidelines.gov> Accessed on: Mar. 2012.

VALENZUELA, A.; SANHUEZA, S. Lípidos estructurados y los sustitutos de grasas: los lípidos del futuro. Aceites y Grasas, v.3, n.72, p.532-540, 2008.

WATANABE, A.; YOKOMIZO, K.; ELIASSON, A.C. Effect of physical states of nonpolar lipids on rheology, ultracentrifugation, and microstructure of wheat flour dough. Cereal Chem., v.80, n.3, p.281-284, 2003.

WHOLE GRAINS COUNCIL. WGC. A quick quiz on whole grains. Available at: $<$ http://wholegrainscouncil.org/files/6. Standards+Definitions.pdf $>$ Accessed on: Apr. 2013.

Received for publication on $23^{\text {rd }}$ August, 2013 Accepted for publication on $09^{\text {th }}$ April 2014 